AperTO - Archivio Istituzionale Open Access dell'Università di Torino

\title{
Is it time for biosimilars in autoimmune diseases?
}

\section{This is the author's manuscript}

Original Citation:

Availability:

This version is available http://hdl.handle.net/2318/142594

since 2016-11-09T12:46:56Z

Published version:

DOI:10.1016/j.autrev.2013.02.005

Terms of use:

Open Access

Anyone can freely access the full text of works made available as "Open Access". Works made available under a Creative Commons license can be used according to the terms and conditions of said license. Use of all other works requires consent of the right holder (author or publisher) if not exempted from copyright protection by the applicable law. 
This Accepted Author Manuscript (AAM) is copyrighted and published by Elsevier. It is posted here by agreement between Elsevier and the University of Turin. Changes resulting from the publishing process - such as editing, corrections, structural formatting, and other quality control mechanisms - may not be reflected in this version of the text. The definitive version of the text was subsequently published in AUTOIMMUNITY REVIEWS, 12, 2013, 10.1016/j.autrev.2013.02.005.

You may download, copy and otherwise use the AAM for non-commercial purposes provided that your license is limited by the following restrictions:

(1) You may use this AAM for non-commercial purposes only under the terms of the CC-BY-NC-ND license.

(2) The integrity of the work and identification of the author, copyright owner, and publisher must be preserved in any copy.

(3) You must attribute this AAM in the following format: Creative Commons BY-NC-ND license (http://creativecommons.org/licenses/by-nc-nd/4.0/deed.en), 10.1016/j.autrev.2013.02.005

The publisher's version is available at:

http://linkinghub.elsevier.com/retrieve/pii/S1568997213000414

When citing, please refer to the published version.

Link to this full text:

http://hdl.handle.net/2318/142594 


\section{Is it time for biosimilars in autoimmune diseases?}

Maria-Jose Cuadrado ${ }^{a}, S_{\text {Savino Sciascia }}{ }^{\mathrm{b}, \mathrm{c}}$, Xavier Bosch ${ }^{\mathrm{d}}$, Munther A. Khamashta ${ }^{\mathrm{c}}$, Manuel Ramos-Casals ${ }^{\mathrm{e}}$

a Louise Coote Lupus Unit, Guy's and St Thomas' NHS Foundation Trust, St Thomas' Hospital, London, UK

b Dipartimento di Malattie Rare, Immunologiche, Ematologiche ed Immunoematologiche, Centro di Ricerche di Immunopatologia e Documentazione su Malattie Rare (CMID), Ospedale Torino Nord Emergenza San G. Bosco ed Università di Torino, Turin, Italy

c Graham Hughes Lupus Research Laboratory, the Rayne Institute, Division of Women's Health, King's College London, UK

a Department of Internal Medicine, Hospital Clinic, University of Barcelona, Spain

e Department of Autoimmune Diseases, Hospital Clinic, University of Barcelona, Spain

\section{Abstract}

The last two decades have witnessed a revolution in the treatment of autoimmune diseases due to the introduction of biological agents which, although now included as standard treatment in patients with autoimmune rheumatological, dermatological and gastrointestinal diseases. The use of biological agents is associated with greater costs compared with the mainly anti-inflammatory and immunosuppressant drugs used in the pre-biological era. Biosimilars are highly similar copies of biological drugs, but not identical to approved 'reference' agents. Biological agents are complex proteins involved in the immune response and their exact replicas are extremely difficult, if not impossible, to obtain. Three scenarios have converged to provide a specific opportunity for biosimilars in autoimmune diseases: growing demand for biologics due to successful clinical use; the nearing of patent expiry for the four top-selling biological brands; and the search to reduce health costs due to the financial crisis. We aimed to review the crucial topics of efficacy, safety and regulatory approach of upcoming biosimilars.

\section{Introduction}

The last two decades have witnessed a revolution in the treatment of autoimmune diseases due to the introduction of biological agents which, although now included as standard treatment in patients with autoimmune rheumatological, dermatological and gastrointestinal diseases, are associated with greater costs compared with the mainly antiinflammatory and immunosuppressant drugs used in the pre-biological era. Biotechnological advances have resulted in the "generic" versions of biologicals, known as biosimilars. The term biosimilar was first used in Pubmed in 2004 [1]. Since then, 7 biosimilar products sold under 13 different names have been licensed in Europe: two human growth hormones (somatropin), three granulocyte-colony stimulating factors (filgrastim), and two erythropoietins that have received different international nonproprietary names, [epoetin-alfa (HX-575) and epoetin-zeta (SB-309)] [2]. 
Three scenarios have converged to provide a specific opportunity for biosimilars in autoimmune diseases: growing demand for biologics due to successful clinical use; the nearing of patent expiry for the four top-selling biological brands; and the search to reduce health costs due to the financial crisis.

The rapid expansion of the biosimilar market is attracting a swarm of pharmaceutical and biotechnology companies to a market estimated at US\$2 billion in the USA alone in 2012 and a projected rise to nearly $\$ 20$ billion by 2018 [3] and [4]. However, physicians may view this as something of a biotechnical bubble, far from the reality of clinical practice as, until now, there is no solid scientific evidence supporting the use of biosimilars in autoimmune diseases. The doubts expressed about the safe, efficacious use of biosimilars seem to augment rather than diminish. Biosimilars are copies of biological agents, which are complex proteins involved in the immune response [overwhelmingly monoclonal antibodies (mAbs)]. Biologicals are a complex collection of large protein isoforms with two crucial functional features: affinity and selectivity, which are highly dependent on post-translational events such as glycosylation[5] and [6]. All alterations result in significant functional variations and, therefore, exact replicas of mAbs are extremely difficult, if not impossible, to obtain [7]. Physiochemical and biological methods of characterizing mAbs are increasingly sophisticated, but comparison of biosimilars to the reference biologic remains difficult. Biosimilar development requires significant investment, technical capability and clinical trial expertise, with estimated average costs of \$200-250 million [8].

Biosimilars are not generic drugs and their licensing requires a different regulatory approach. Europe was the first region to establish specific regulatory approval processes for biosimilars, based on scientific data and maintaining the stringent standards required for the original biologic. The Biosimilar Medicinal Products Working Party (BMWP) of the European Medicines Agency (EMA) Committee for Medicinal Products for Human Use (CHMP) has launched various guidelines and rules for the use of biosimilars containing biotechnology-derived proteins (572643/2011 and 572828/2011), with an updated review discussing and accepting external amendments. The EMA guidelines on biosimilars based on mAbs (632613/2009 and 403543/2010) clearly differentiate between those with cytotoxic mechanisms of actions (mainly anti-cancer mAbs) and immunomodulatory mAbs (overwhelmingly used in autoimmune diseases). The main objective is to establish non-clinical and clinical requirements to guide applicants for standardized development programs. The USA lags somewhat behind Europe in this field, since the Food and Drug Administration (FDA) has not yet issued a specific regulatory pathway similar to the EMA proposal. The Biologics Price Competition and Innovation (BCPI) Act outlined shortened approval processes for "highly similar" biologic products, enabling evaluation of biosimilars against a single, already-licensed, reference biologic therapy [9]. In February 2012, the FDA issued draft industry guidance on implementation of the BPCI Act approval process.

The World Health Organization (WHO) also provided norms and standards for the evaluation of these products in 2009 [10]. Written standards established through the Expert Committee on Biological Standardization at the WHO (ECBS) may serve as a basis for setting national requirements for production, quality control and overall regulation of biological medicines. These norms require documentation of the manufacturing process, preclinical physiochemical studies, toxicity study in animals, clinical pharmokinetic studies comparing the biosimilar product to the original biological, phase III clinical efficacy studies, immunogenicity studies in humans, and an appropriated pharmacovigilance plan.

However, controversy is anticipated with interests supporting or opposing the biosimilar approval pathway [11]. 
Some government agencies in Asia (e.g. Japan, Malaysia, Singapore, South Korea, Sri Lanka and Taiwan) have established their own regulatory pathways for the evaluation and approval of biosimilar agents, which may differ from EMEA and FDA positions.

At present, China is developing regulations that specify requirements for the evaluation and approval of biosimilars based on the WHO guidance, although biosimilar agents to treat patients with rheumatic diseases are already commercialized [12].

Efforts are centered mainly on developing biosimilars for the four most-frequently used biological agents, whose patents expire in the next few years (Table 1).

\section{Rituximab}

The development of rituximab biosimilars is ongoing. Reditux $\AA$, a rituximab copy manufactured by India-based generic drug manufacturer, Dr Reddy's Laboratories, was the first intended copy of mAb launched, being introduced in India in April 2007 at $50 \%$ of the original price. Likewise, Kikuzubam ${ }^{\circledR}$ is manufactured by the Mexican firm, Probiomed, and is used in Mexico, Bolivia, Peru and Chile. Several companies are conducting phase I and II studies of rituximab biosimilars in rheumatoid arthritis (Table 1). The completion of Boehringer Ingelheim's phase III trial of its rituximab biosimilar (BI 695500) is expected in April 2015. However, recent communications have cast a shadow on the extremely-rapid, seemingly-promising development of biosimilars. In October 2012, Teva suspended plans for a phase III clinical trial of its rituximab biosimilar in rheumatoid arthritis, while Samsung Electronics has also temporarily ceased clinical development of its biosimilar [13]. Exact reasons were not given in either case, but it would be interesting to know whether economic and/or technical reasons were involved.

\section{Infliximab and adalimumab}

In February 2012, Celltrion announced the successful completion of a clinical program of its infliximab biosimilar, Remsima ${ }^{\circledR}$ (CT-P13) including 874 patients with active rheumatoid arthritis (257 patients in phase I; 617 patients in phase III) from 100 hospitals in 19 countries. The 30-week phase III trial measuring American College of Rheumatology $20 \%$ improvement criteria (ACR20) had response rates of $73 \%$ with Remsima ${ }^{\circledR}$ and $70 \%$ with original infliximab, and found no significant pharmacokinetic differences between the biosimilar and the original [14]. Infection-related adverse advents were reported in $46(15 \%)$ and 51 (17\%) patients in the CT-P13 and infliximab arms, respectively, and tuberculosis in 3 and 1 patients, respectively.

Preliminary positive results of a phase I randomized controlled trial in 250 ankylosing spondylitis patients were presented at the last EULAR meeting [15].

In late July 2012, the Korean Food and Drug Administration (KFDA) approved Remsima ${ }^{\circledR}$ for use in RA, Crohn's disease, ulcerative colitis, ankylosing spondylitis, and psoriatic arthritis. The price is $30 \%$ lower than the current original Infliximab price and it is already commercially available. According to the September 2012 EMA list of applications for new human medicines under CHMP evaluation, two applications for biosimilar versions of infliximab will be reviewed. Adalimumab will lose patent protection in the USA, Japan and European Union in 2016, 2017 and 
2018, respectively, and companies are working to develop adalimumab-based biosimilars for the same indication of the original biological.

\section{Etanercept}

In October 2009, the Taiwan-based Mycenax announced its etanercept biosimilar, TuNEX®, had successfully completed phase I trials in 23 healthy Korean male volunteers[16]. A Taiwanese phase III study is underway and Mycenax is seeking partners for its introduction in other markets. Other etanercept intended copies are currently marketed in China (Yisaipu) and Colombia (Etanar), and the HD203 compound is under evaluation in Korean RA patients [17].

\section{Immunogenecity}

The number and diversity of reported autoimmune diseases triggered by biological agents has increased in parallel with their increasing use [18] and [19]. Biological agents have been related with the development of advert events including autoimmune process [20] and physicians should bear this in mind when biosimilars are postulated as therapies for autoimmune diseases. Impurities in biological products, structural modifications resulting from the manufacturing and/or suboptimal storage conditions can increase the risk of immunogenicity, leading to the possible production of antibodies against any biosimilar component [21]. Human anti-monoclonal antibodies (HAMAs) may bind to and attenuate or inactivate the biosimilar, resulting in hypersensitivity reactions such as allergy or serum sickness, or even unexpected autoimmune effects. This was reported in 2002, when some patients treated with a recombinant erythropoietin developed autoimmune-related pure red-cell anemia [22] and [23].

\section{Current and future perspectives}

Currently, there is a startling disconnect between the development of biosimilars and the scarcity of scientific information on their safety and efficacy in patients with autoimmune diseases. For example, at the 2012 European League Against Rheumatism (EULAR) and ACR meetings, only two abstracts on the use of biosimilars in autoimmune diseases were presented [14] and [15]. Physicians probably know the concept and potential cost-benefits but require further evidence before accepting that biosimilars are effective, safe, cheaper options to biologics. The outlook is further complicated by the fact that the regulatory rules for biosimilars are at very-different stages in the US, European and pharmemergingmarkets and even vary by country.

Transparency regarding the results of ongoing trials (especially with respect to emerging safety issues) and involvement in the planning and conduct of future trials and regulatory rules is required. Feedback on the EMA draft guidelines mainly comes from representatives of regulatory agencies, pharmaceutical companies and patient organizations, but not from any national or European medical associations. As stated by Ebbers et al. [24], "when regulators fail to involve doctors in their activities, this will impede the acceptance of the cost-effective and innovative medicinal products of the future." Greater engagement between regulatory authorities, pharmaceutical companies and the medical community would be welcome to be sure that the full process, from synthesis to manufacturing meets the highest standard to guarantee efficacy and safety. The potential save in cost related to biosimilar use should not have an impact in the outcome of our patients. 
Take-home messages

- Biological agents represent a revolution in the treatment of autoimmune diseases.

- Biosimilars are not "generic" of biological agents as biological cannot be copied.

- Biosimilars' license requires a different regulatory approach from generic ones.

- Biosimilar may represent a potential save in cost.

- The highest standards in manufacturing are required to guarantee efficacy and safety.

\section{References}

[1] Ebbers HC, Crow SA, Vulto AG, Schellekens H. Interchangeability, immunogenicity and biosimilars. Nat Biotechnol 2012;30:1186-90.

[2] Schellekens H. How similar do ‘biosimilars' need to be? Nat Biotechnol 2004;22: 1357-9.

[3] Global Biosimilars Market — Products, Applications and Regulations. Wall St J November 292012 http://online.wsj.com/article/PR-CO-20121129-911513.html? mod=crnews (accessed December 12, 2012). [4] Leardini G, Rigon C. The impact of the profile of biologics on treatment costs.Autoimmun Rev Dec 3 2012 [Epub ahead of print].

[5] Tan Q, Guo Q, Fang C, Wang C, Li B, Wang H, et al. Characterization and comparison of commercially available TNF receptor 2-Fc fusion protein products. MAbs 2012;4:761-74.

[6] Atzeni F, Benucci M, Sallì S, Bongiovanni S, Boccassini L, Sarzi-Puttini P. Different effects of biological drugs in rheumatoid arthritis.Autoimmun Rev Dec 32012 [Epub ahead of print].

[7] Epis OM, Giacomelli L, Deidda S, Bruschi E. Tight control applied to the tight control applied to the biological therapy of rheumatoid arthritis.Autoimmun Rev Dec 32012 [Epub ahead of print].

[8] What's ahead for biosimilars? Pharmavoice.http:/www.imshealth.com/ims/

Global/Content/Corporate/Press\%20Room/IMS\%20in\%20the\%20News/Documents/ PharmaVOICE0212IMS-Biosimilars.pdf; February 2012 . [accessed December 12, 2012].

[9] Kay J. Biosimilars: a regulatory perspective from America. Arthritis Res Ther 2011;13:112.

[10] Health Canada Health Products and Food Branch. Guidance for sponsors: information and submission requirements for subsequent entry biologics (SEBs) Health Canada. [online] http://www.hc-sc.gc.ca/dhpmps/alt_formats/pdf/brgtherap/applic-demande/ guides/seb-pbu/seb-pbu-2010-eng.pdf; 2010.

[11] Approval of biosimilars in the USA — dead ringers? Lancet 2012;379:686-6.

[12] Liang C, Wang J. China's perspective on similar biotherapeutic products. Biologicals 2011;39:312-6.

[13] Samsung halts clinical tests for rituximab biosimilar.Biosimilars News; October 182012

[http://www.biosimilarnews.com/samsung-halts-clinical-tests-for-rituximabbiosimilar. (accessed December 12, 2012)].

[14] Yoo D, Miranda P, Piotrowski M, Ramiterre E, Kovalenko V, Prodanovic N, et al. A randomized, double-blind, phase 3 study demonstrates clinical equivalence of ct-p13 to infliximab when co-administered with methotrexate in patients with active rheumatoid arthritis. Ann Rheum Dis 2012;71(Suppl. 3):359.

[15] Park W, Hrycaj P, Kovalenko V, Miranda P, Gutierrez-Ureña S, Lee Y, et al. A randomized, doubleblind, phase 1 study demonstrates equivalence in pharmacokinetics, safety, and efficacy of ct-p13 and infliximab in patients with ankylosing spondylitis. Ann Rheum Dis 2012;71(Suppl. 3):111.

[16] Gu N, Yi S, Kim TE, Kim J, Shin SG, Jang IJ, et al. Comparative pharmacokinetics and tolerability of branded etanercept (25 mg) and its biosimilar $(25 \mathrm{mg})$ : a randomized, open-label, single-dose, two-sequence, crossover study in healthy Korean male volunteers. Clin Ther 2011;33:2029-37.

[17] Yi S, Kim SE, Park MK, Yoon SH, Cho JY, Lim KS, et al. Comparative pharmacokinetics of HD203, a biosimilar of etanercept, with marketed etanercept (Enbrel®): a double-blind, single-dose, crossover study in healthy volunteers. BioDrugs 2012;26: 177-84.

[18] Ramos-Casals M, Brito-Zerón P, Muñoz S, Soria N, Galiana D, Bertolaccini L, et al. Autoimmune diseases induced by TNF-targeted therapies: analysis of 233 cases. Medicine 2007;86:242-51.

[19] Atzeni F, Talotta R, Benucci M, et al. Immunogenicity and autoimmunity during anti-TNF therapy.Autoimmun Rev Nov 302012 [Epub ahead of print]. 
[20] Perez-Alvarez R, Pérez-de-Lis M, Ramos-Casals M, on behalf of the BIOGEAS study group. Biologicsinduced autoimmune diseases. Curr Opin Rheumatol 2013;25: 56-64.

[21] Roger SD, Mikhail A. Biosimilars: opportunity or cause for concern? J Pharm Pharm Sci 2007;10:40510.

[22] Gershon SK, Luksenburg H, Coté TR, Braun MM. Pure red-cell aplasia and recombinant erythropoietin. N Engl J Med 2002;346:1584-6.

[23] Bennett CL, Luminari S, Nissenson AR, Tallman MS, Klinge SA, McWilliams N, et al. Pure red-cell aplasia and epoetin therapy. N Engl J Med 2004;351:1403-8. [24] Ebbers HC, Pieters T, Leufkens HG, Schellekens H. Effective pharmaceutical regulation needs alignment with doctors. Drug Discov Today 2012;17:100-3.

Table 1.

Pipeline for development of biosimilars in autoimmune diseases.

\begin{tabular}{|c|c|c|c|}
\hline Drug & $\begin{array}{l}\text { Correspondent } \\
\text { biological }\end{array}$ & $\begin{array}{l}\text { Manufacturer } \\
\text { (location) }\end{array}$ & Primary outcome measures \\
\hline \multicolumn{4}{|l|}{ Preclinical trails } \\
\hline Avent ${ }^{\mathrm{TM}}$ & Etanercept & Avesthagen (India) & Efficacy and toxicity \\
\hline PRX-106 & Etanercept & $\begin{array}{l}\text { Protalix } \\
\text { Biotherapeutics } \\
\text { (Israel) }^{\mathrm{a}}\end{array}$ & Efficacy and toxicity \\
\hline \multicolumn{4}{|l|}{$\begin{array}{l}\text { Clinical trials } \\
\left(\text { phase } / \text { state }^{c}\right)\end{array}$} \\
\hline $\begin{array}{l}\text { BI695501 } \\
\text { (I/completed) }\end{array}$ & Adalimumab & $\begin{array}{l}\text { Boehringer Ingelheim } \\
\text { Pharmaceuticals } \\
\text { (Germany) }\end{array}$ & $\begin{array}{l}\text { - Area under the concentration-time } \\
\text { curve of the analyte in plasma over the } \\
\text { time interval from } 0 \text { extrapolated to } \\
\text { infinity [Time Frame: } 72 \text { days] } \\
\text { - Maximum measured concentration } \\
\text { of the analyte in plasma [Time Frame: } \\
72 \text { days] }\end{array}$ \\
\hline $\begin{array}{l}\text { LBEC0101 } \\
\left(\mathrm{I} / \text { completed }^{\mathrm{c}}\right.\end{array}$ & Etanercept & $\begin{array}{l}\text { LG Life Sciences Ltd. } \\
\text { (South Korea) }\end{array}$ & $\begin{array}{l}\text { Etanercept levels in blood [time } \\
\text { frame: } 22 \text { day] }\end{array}$ \\
\hline $\begin{array}{l}\text { CT-P10 (I in } \\
\text { AR/recruiting) }\end{array}$ & Rituximab & $\begin{array}{l}\text { Celltrion (South } \\
\text { Korea) }\end{array}$ & $\begin{array}{l}\text { Compare pharmacokinetics in terms } \\
\text { of } C_{\max } \text { [time frame: up to week 24] }\end{array}$ \\
\hline $\begin{array}{l}\text { PF-05280586 (I } \\
\text { and II in } \\
\text { AR/recruiting) }\end{array}$ & Rituximab & Pfizer (US) & $\begin{array}{l}\text { Pharmacokinetic parameter } C_{\max } \text { [time } \\
\text { frame: week 25] } \\
\text { Pharmacokinetic parameter AUC } 0-\infty \\
\text { [Time Frame: Week 25] }\end{array}$ \\
\hline $\begin{array}{l}\text { GP2013 (I and II in } \\
\text { AR/recruiting) }\end{array}$ & Rituximab & $\begin{array}{l}\text { Sandoz } \\
\text { Biopharmaceuticals } \\
\text { (Switzerland) }\end{array}$ & $\begin{array}{l}\text { Compare pharmacokinetics of GP2013 } \\
\text { and rituximab following IV infusion in } \\
\text { patients with RA [time frame: } \\
24 \text { weeks] }\end{array}$ \\
\hline $\begin{array}{l}\text { TL011 (I and II in } \\
\text { AR/completed) }\end{array}$ & Rituximab & $\begin{array}{l}\text { Teva Pharmaceutical } \\
\text { Industries (Israel) }\end{array}$ & $\begin{array}{l}\text { Compare pharmacokinetics of } \\
\text { rituximab following IV infusions of } \\
\text { TL011 and MabThera }{ }^{\circledR} \text { in subjects } \\
\text { with RA }\end{array}$ \\
\hline $\begin{array}{l}\text { HD203 (I and III in } \\
\text { AR/completed; } \\
\text { Active, not } \\
\text { recruiting) }\end{array}$ & Etanercept & $\begin{array}{l}\text { Hanwha Chemical } \\
\text { (South Korea) }\end{array}$ & $\begin{array}{l}\text { Etanercept levels in blood [time } \\
\text { frame: } 21 \text { days] } \\
\text { - To prove the equivalence between } \\
\text { two groups by comparing the ACR } 20 \\
\text { of W24 with the baseline after } \\
\text { injecting HD203 and Enbrel } ₫ \text { into } \\
\text { rheumatoid arthritis patients for } \\
24 \text { weeks }\end{array}$ \\
\hline TuNEX (III) $^{\mathrm{c}}$ & Etanercept & $\begin{array}{l}\text { Mycenax Biotech } \\
\text { (Taiwan) }\end{array}$ & $\begin{array}{l}\text { The primary efficacy endpoint is } \\
\text { defined as ACR2 } 0 \text { responder at last } \\
\text { treatment visit (Week 24). }\end{array}$ \\
\hline
\end{tabular}




\begin{tabular}{|c|c|c|c|}
\hline Drug & $\begin{array}{l}\text { Correspondent } \\
\text { biological }\end{array}$ & $\begin{array}{l}\text { Manufacturer } \\
\text { (location) }\end{array}$ & Primary outcome measures \\
\hline $\begin{array}{l}\text { CT-P13 (I in AS } \\
\text { and III in AR/active, } \\
\text { not recruiting) }\end{array}$ & Infliximab & $\begin{array}{l}\text { Celltrion (South } \\
\text { Korea) }\end{array}$ & $\begin{array}{l}\text { Long term efficacy evaluated by } \\
\text { American College of Rheumatology } \\
\text { (ACR) criteria and Long term safety } \\
\text { evaluated by immunogenicity and } \\
\text { clinical laboratory test [time frame: up } \\
\text { to week 40] }\end{array}$ \\
\hline \multicolumn{4}{|l|}{ Marketed (location) } \\
\hline Yisaipu (China) & Etanercept & $\begin{array}{l}\text { Shanghai CP Goujian } \\
\text { Pharmaceutical Co. } \\
\text { (China) }\end{array}$ & \\
\hline $\begin{array}{l}\text { Etanar } \AA \\
\text { (Colombia) }\end{array}$ & Etanercept & $\begin{array}{l}\text { Shanghai CP Goujian } \\
\text { Pharmaceutical Co. } \\
\text { (China) }\end{array}$ & \\
\hline $\begin{array}{l}\text { Reditux }{ }^{\circledR} \text { (Bolivia, } \\
\text { Chile, India and } \\
\text { Peru) }\end{array}$ & Rituximab & $\begin{array}{l}\text { Dr Reddy's } \\
\text { Laboratories (India) }\end{array}$ & \\
\hline $\begin{array}{l}\text { Kikuzubam }{ }^{\circledR} \\
\text { (Bolivia, Chile, } \\
\text { Mexico, and Peru) }\end{array}$ & Rituximab & Probiomed (Mexico) & \\
\hline \multicolumn{4}{|l|}{$\begin{array}{l}\text { Development or } \\
\text { pipeline }\end{array}$} \\
\hline Development & $\begin{array}{l}\text { Adalimumab, } \\
\text { rituximab }\end{array}$ & $\begin{array}{l}\text { BioXpress } \\
\text { Therapeutics S. A. } \\
\text { (Switzerland) }\end{array}$ & \\
\hline Pipeline & $\begin{array}{l}\text { Abatacept, } \\
\text { Etanercept, } \\
\text { Golimumab, } \\
\text { Infliximab, } \\
\text { Tocilizumab }\end{array}$ & $\begin{array}{l}\text { BioXpress } \\
\text { Therapeutics S. A. } \\
\text { (Switzerland) }\end{array}$ & \\
\hline
\end{tabular}

AS: ankylosing spondylitis; AR: rheumatoid arthritis.

a http:/www.avesthagen.com/docs/020910pr.pdf

b http://www.protalix.com/index.asp.

c Data from clinicaltrails.gov at February 2013. 